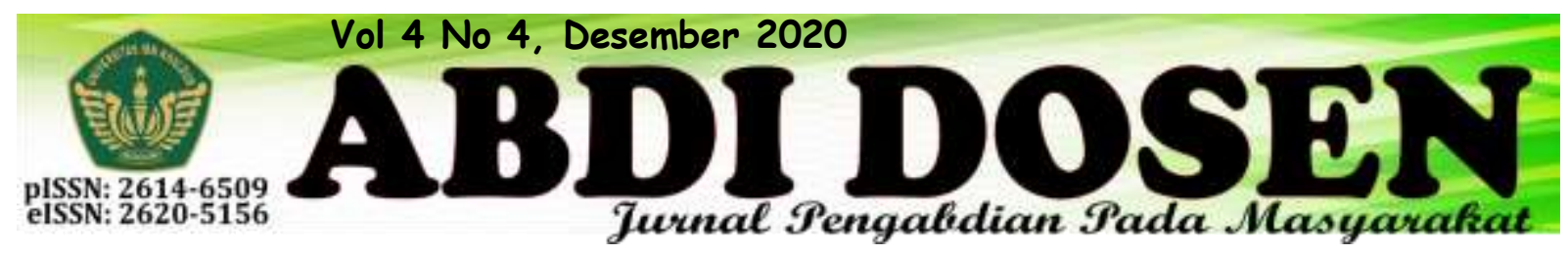

\title{
SOSIALISASI PELUANG USAHA INFUSED WATER PADA MASA PANDEMI COVID-19 DI DESA PEMAGARSARI
}

\author{
Lestari Safitri ${ }^{1}$ dan Immas Nurhayati ${ }^{2}$ \\ lestarisafitri98@gmail.com ${ }^{1}$ \\ immasnurhayati1@gmail.com ${ }^{2}$ \\ Fakultas Ekonomi dan Bisnis Universitas Ibn Khaldun Bogor ${ }^{1,2}$
}

\begin{abstract}
The Covid-19 pandemic that is currently happening has had a major impact on health, education and the economy, and has claimed many victims. The public must maintain their respective health so they are not exposed to the Covid-19 virus and stabilize their finances to survive. Infused water can be used as a business opportunity during a pandemic and helps people maintain endurance. This study aims to increase the knowledge of residents in Pemagarsari Village in opening business opportunities during the pandemic. The research method used in this study is a qualitative method. The results showed that the residents were very enthusiastic in the socialization of infused water business opportunities and increased their knowledge about infused water.
\end{abstract}

Keywords: Covid-19 Pandemic, Business Opportunities, Infused Water

\begin{abstract}
ABSTRAK
Pandemi covid-19 yang sedang terjadi kala ini sangat berdampak pada kesehatan, pendidikan, dan ekonomi, serta telah banyak menelan korban. Masyarakat harus menjaga kesehatan masingmasing agar tidak terpapar virus covid-19 dan menstabilkan keuangannya untuk bertahan hidup. Infused water bisa dijadikan sebagai peluang usaha pada masa pandemic serta membantu masyarakat dalam menjaga daya tahan tubuh. Penelitian ini bertujuan untuk menambah pengetahuan warga di Desa Pemagarsari dalam membuka peluang usaha di masa pandemi. Metode penelitian yang digunakan dalam penlitian ini adalah metode kualitatif. Hasil penelitian menunjukkan bahwa warga sangat antusias dalam pelaksanaan kegiatan sosialisasi peluang usaha infused water dan menambah pengetahuan warga mengenai infused water.
\end{abstract}

\section{Kata kunci: Pandemi Covid-19, Peluang Usaha, Infused Water}

\section{PENDAHULUAN}

Pandemi covid-19 yang sedang terjadi kala ini sangat berdampak pada kesehatan, pendidikan, dan ekonomi, serta telah banyak menelan korban. Masyarakat harus menjaga kesehatan masing-masing agar tidak terpapar virus covid-19 dan menstabilkan keuangannya untuk bertahan hidup. Berbagai cara dilakukan untuk menjaga daya tahan tubuh senantiasa normal, seperti mengkonsumsi vitamin, sayur dan buah. Konsumsi air yang cukup juga sangat dibutuhkan tubuh agar tidak terjadi dehidrasi dan tubuh menjadi lemas sehingga virus dari mana saja bisa masuk ke 
dalam tubuh. Air merupakan komponen utama dalam tubuh manusia. Tidak ada satu pun reaksi kimia dalam tubuh dapat berlangsung tanpa adanya air (Desty Ervira Puspaningtyas \& Yunita Indah, 2014). Tetapi, orang-orang saat ini kurang menyukai mengkonsumsi air putih, mereka lebih suka air yang bercorak, berasa serta siap saji. Untuk mengakali ketidaksukaan orang-orang dengan air putih muncullah minuman infused water. Infused water kembali nge-tren di masa pandemi ini karena dipercaya berkhasiat bagi kesehatan tubuh. Dan bisa menjadi pilihan mengkonsumsi air putih dengan rasa buah yang menyatu bersama air, sekaligus dijadikan kesempatan peluang usaha di masa pandemi covid-19.

Peluang usaha infused water cukup sangat menjanjikan di masa pandemi covid19. Terlebih perekenomian yang menyusut semenjak adanya virus ini serta bahanbahan pokok yang seketika naik harga. Dampak pandemi ini sangat dirasakan masyarakat, terutama pekerja yang terpaksa di PHK (Pemutusan Hubungan Kerja) oleh perusahaan, sebab bekurangnya pendapatan perusahaan sehingga tidak sanggup untuk menggaji seluruh karyawan. Sebagian orang mulai membuka usaha di masa pandemi, seperti usaha masker, hand sanitizer, dan produk-produk lainnya.

Maka dari itu penulis ingin mengajak warga di Desa Pemagarsari untuk membuka peluang usaha infused water atau jenis usaha lainnya yang dapat menguntungkan, tidak hanya menguntungkan secara finansial tetapi juga menguntungkan pada kesehatan.

\section{Rumusan Masalah}

a. Apa yang menjadi kelebihan usaha infused water?

b. Bagaimana strategi pemasaran infused water?

\section{Tujuan Penelitian}

Tujuan penelitian ini adalah untuk menambah pengetahuan masyarakat dalam berwirausaha khususnya pada usaha infused water. Menambah pengetahuan masyarakat mengenai pentingnya menjaga kesehatan di masa pandemi sambil berwirausaha. Dan dapat membantu meningkatkan pendapatan jika usaha ini dilaksanakan.

\section{Urgensi Penelitian}

Penelitian ini dilakukan untuk melatih masyarakat di Desa Pemagarsari dalam berinovasi membuka peluang usaha di masa pandemi covid-19, seperti infused water dan menambah pengetahuan masyarakat dalam berwirausaha. Sehingga dapat menambah pendapatan sekaligus menjaga kesehatan di masa pandemi.

\section{Manfaat Penelitian}

1. Mencipatakan interaksi yang baik antar sesama masyarakat.

2. Menambah pengetahuan masyarakat dalam membuka usaha, khusunya pada usaha infused water.

3. Masyarakat dapat membuka usaha infused water di masa pandemi covid19.

4. Dapat menambah pendapatan dari hasil usaha infused water. 


\section{METODE PENELITIAN}

Metode penelitian ini menggunakan metode kualitatif dengan pengumpulan data berdasarkan observasi dan dokumentsi.

Menurut Denzin \& Lincoln (1994) menyatakan bahwa penelitian kualitatif adalah penelitian yang menggunakan latar alamiah dengan maksud menafsirkan fenomena yang terjadi dan dilakukan dengan jalan melibatkan berbagai metode yang ada. Erickson (1968) menyatakan bahwa penelitian kualitatif berusaha untuk

\section{HASIL PENELITIAN}

Dari hasil observasi penulis bahwa sebagian masyarakat di lingkungan sekitar masih mengandalkan kepala keluarga sebagai sumber pendapatan untuk mencukupi kebutuhan sehari-hari, tetapi ada juga yang suami, istri atau anaknya bekerja dalam satu keluarga. Beberapa warga membuka usaha dirumah masingmasing seperti toko sembako, jajanan gorengan, sosis bakar, baso goreng, pop ice, cappuccino cincau dan lain sebagainya. Beberapa dari masyarakat tersebut pasti merasa khawatir jika anaknya atau keluarga lainnya sering mengkonsumsi jajanan makanan dan minuman yang tidak diketahui kebersihannya dan manfaatnya pada tubuh, apalagi di masa pandemi covid19 ini yang harus mengutamakan kesehatan. Maka dari itu penulis berinsiatif untuk mensosialisasikan minuman infused water kepada masyarakat sekitar sebagai peluang usaha di masa pandemi covid-19 yang dapat menambah pendapatan sekaligus memberi kesehatan pada tubuh.

Pelaksanaan kegiatan sosialisasi infused water sebagai peluang usaha pada masa pandemi covid-19 ini dilakukan pada tanggal 25 September 2020, dengan empat orang warga yang antusias dengan infused menemukan dan menggambarkan secara naratif kegiatan yang dilakukan dan dampak dari tindakan yang dilakukan terhadap kehidupan mereka. (Anggito \& Johan Setiawan, 2018).

Observasi dilakukan dengan mengamati lingkungan sekitar Desa Pemgarsari, khususnya di lingkungan RT 05 RW 01. Dan melakukan dokumentasi saat pelaksanaan kegiatan sosialisasi.

water. Tentunya dalam kegiatan ini tetap melaksanakan protokol kesehatan. Adapun kegiatan yang dilakukan yaitu:

a. Penyampaian materi mengenai infused water

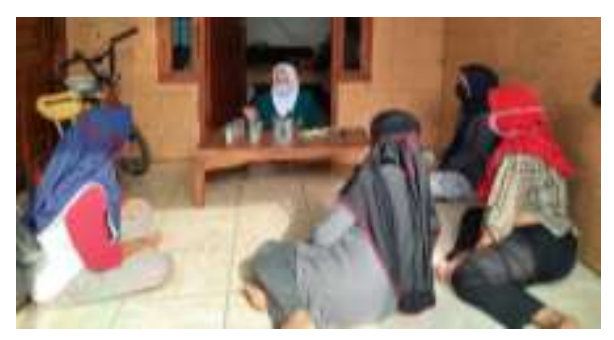

Gambar 1. Penyampaian materi Sumber: Dokumentasi pribadi

\section{Apa itu Infused Water?}

Infused water adalah air yang diberi tambahan potongan buah atau herbal sehingga memberikan cita rasa dan manfaat untuk kesehatan. Infused water dibuat dengan cara memasukkan irisan buah-buahan atau herbal ke dalam air putih, kemudian didiamkan beberapa jam sampai sari buahnya keluar dan air akan berasa buah (Noni Soraya, 2014).

Infused water bisa digunakan bagi mereka yang tidak suka mengkonsumsi buah dan air 
putih. Dengan adanya irisan potongan buah yang berwarnawarni di dalam air bisa memancing seseorang untuk tertarik dan suka dengan buah dan air.

Buah yang bisa digunakan untuk membuat infused water biasanya adalah buah lemon, strawberry, kiwi, Selain menggunakan buah, membuat infused water juga bisa menggunakan rempah-rempah seperti jahe, daun mint, daun kemangi, batang serai, kayu manis, dan bahan rempah lainnya.

\section{Manfaat Infused Water}

Infused water dipercaya dapat mendetoksifikasi tubuh dan mengeluarkan racun yang menumpuk dalam tubuh. Adapun manfaat dari infused water yaitu:

1. Memperbaiki suasana hati;

2. Menghilangkan racun dari sistem tubuh;

3. Membuat kamu kenyang sehingga kamu tidak banyak makan;

4. Secara alami membantu tubuh melepaskan sel-sel lemak untuk menurunkan berat air;

5. Membantu pencernaan;

6. Menjaga agar organ tetap sehat;

7. Mengurangi kelelahan otot saat berolahraga;

8. Membantu seseorang pulih lebih cepat usia olahraga;

9. Membuat seseorang tidak merasa pusing di sore hari;

10. Meningkatkan sistem imun;

11. Meningkatkan energi.
Kekurangan dari Infused Water

Buah lemon adalah buah yang paling sering digunakan untuk campuran infused water, karena dipercaya dapat membuat tubuh bugar dan menurunkan berat badan. Namun, infused water ini tidak disarankan untuk dikonsumsi setiap hari ataupun berlebihan, karena khasiatnya juga belum terbukti secara pasti. Jika dikonsumsi secara berlebihan dapat memberikan efek samping sebagai berikut:

1. Kerusakan gigi

2. Sakit perut

3. Sariawan

4. Memicu migrain

b. Praktik Membuat Infused Water Dalam membuat infused water ini sangat mudah sekali, bahan-bahan yang digunakan juga mudah ditemukan. Adapun langkahlangkah membuat infused water:

Bahan-bahan yang dibutuhkan:

- Lemon 2 buah

- Strawberry 20 buah

- Kiwi 1 buah

- Daunt mint secukupnya

- Air 5 liter

- Botol plastic ukuran $250 \mathrm{ml} \mathrm{:} 20$ botol

Cara membuat infused water:

1. Iris buah lemon menjadi 20 bagian

2. Iris 1 buah strawberry menjadi 3 bagian

3. Iris buah kiwi menjadi 20 bagian

4. Masukkan buah-buah tersebut ke dalam botol, dengan pembagian yang sama ke 20 botol 
5. Masukkan air mineral ke dalam masing-masing, tutup botol hingga rapat

6. Untuk mendapatkan hasil yang maksimal, campuran air dan buah-buahan ini dimasukkan ke dalam lemari es selama minimal 4 jam. Infused water dapat bertahan sekitar 3 hingga 5 hari bergantung pada jenis buah atau tanaman herbal yang digunakan. (Christian, Abri Anton Trisno, \& Hamsal, 2014)

Selain campuran buah-buah diatas juga bisa mencampurkan beberapa jenis buah lainnya, seperti di bawah ini:

- Infused water dari strawberry, belimbing dan daun mint

- Infused water dari lemon, timun dan daun mint

- Infused water dari apel, kiwi dan semangka

- Infused water dari pir, jeruk nipis dan jahe

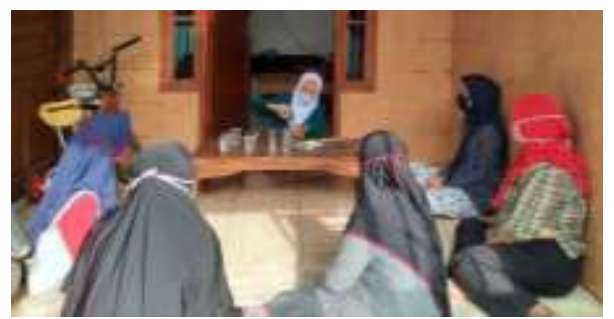

Gambar 3. Praktik membuat infused water

Sumber: Dokumentasi pribadi

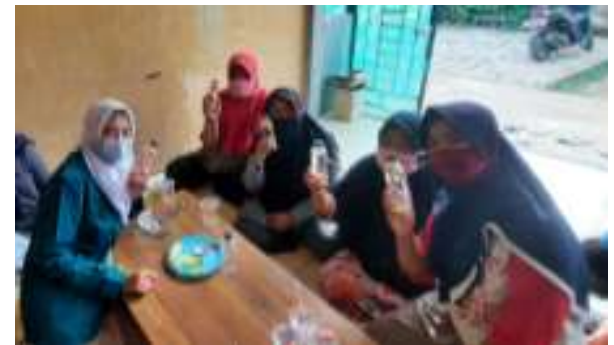

Gambar 3. Praktik membuat infused water Sumber: Dokumentasi pribadi

c. Infused Water menjadi Peluang Usaha

Infused water merupakan peluang usaha yang sangat menjanjikan di masa pandemi covid-19. Dimana setiap orang harus menjaga kesehatan daya tahan tubuhnya agar tidak terpapar virus covid-19. Dengan usaha infused water memudahkan konsumen yang ingin mengkonsumsi infused water tidak perlu repot-repot dalam membuatnya. 


\section{PEMBAHASAN}

Pembahasan dari hasil kegiatan sosialisasi peluang usaha infused water pada masa pandemi covid-19, bahwa warga yang mengikuti sosialisasi sangat antusias dengan usaha infused water. Karena infused water merupakan peluang usaha yang sangat menjanjikan di masa pandemi covid19. Dimana setiap orang harus menjaga kesehatan daya tahan tubuhnya agar tidak terpapar virus covid-19. Dengan usaha infused water memudahkan konsumen yang ingin mengkonsumsi infused water tidak perlu susah payah dalam membuatnya. Sehingga dengan membuat usaha infused water dapat membantu perekonomian mereka.

Adapun strategi pemasaran usaha infused water:

1. Segmentasi pasar

Segmen pasar dari minuman infused water adalah orang-orang yang peduli terhadap kesehatan, anak muda yang banyak beraktifitas,

\section{KESIMPULAN}

Dengan adanya kegiatan sosialisasi peluang usaha infused water pada masa pandemi covid-19 ini dapat menambah pengetahuan dan informasi pada masyarakat dalam membuka usaha, seperti usaha infused water. Menimbulkan kesadaran masyarakat terhadap pentingnya mengkonsumsi makanan dan minuman yang sehat di masa pandemi. Menimbulkan orang lanjut usia, karyawan kantor, dan bisa juga dijadikan souvenir acara semi formal maupun formal.

2. Target pasar

Target pasar infused water adalah car free day, bazar, kampus, instansi/lembaga, wedding, dan lain-lain. Saat pandemi covid-19 setiap usaha memaksimalkan penjualan secara online memanfaatkan sosial media sebagai jembatan untuk mempromosikan produk.

3. Positioning

Dalam membuka usaha tentunya dibutuhkan hubungan baik antara penjual dengan pembeli, sebagai permulaan agar adanya hubungan baik dan kembeli akan mengingat produk yang kita jual. Harus adanya strategi penjualan seperti mengadakan promo-promo yang dapat menarik perhatian konsumen.

rasa percaya diri dan semangat pada masyarakat dalam berwirausaha. Dan jika usaha infused water ini ditekuni dan rajin dalam memasarkannya serta mempunyai banyak koneksi untuk menjual infused water, usaha ini bisa menambah atau meningkatkan pendapatan masyarakat itu sendiri. 


\section{DAFTAR PUSTAKA}

Anggito, A., \& Johan Setiawan, S. (2018). Metodologi Penelitian Kualitatif. Sukabumi: CV Jejak.

Christian, A., Abri Anton Trisno, V. S., \& Hamsal, M. (2014). Perencanaan Model Bisnis Infused Water.

Desty Ervira Puspaningtyas, S., \& Yunita Indah, S. (2014). Variasi Favorit Infused Water Berkhasiat. Jakarta Selatan: FMedia (Imprint AgroMedia Pustaka).

Lubis, A. N. (2004). Strategi Pemasaran dalam Persaingan Bisnis. 2-4.
Noni Soraya, M. (2014). Infuses Water: Minuman Bervitamin \& Super Sehat.

https://www.halodoc.com/artikel/adakahefek-samping-dari-minum-infused-water

https://www.halodoc.com/artikel/waktupaling-baik-mengonsumsi-infused-water

https://docplayer.info/50846521-

Perencanaan-model-bisnis-infusedwater.html 